\title{
Пашкова А.A.
}

\section{Миграционные потоки и население Сортавалы в XVII-начале XVIII века}

Петрозаводский государственный университет (Россия, Петрозаводск)

doi: 10.18411/trnio-11-2021-131

\section{Аннотация}

В статье рассматривается демографическая история города Сортавалы на протяжении конца XVII - начала XVIII века. Источниками по данному вопросу послужили труды дореволюционных финских ученых. Статья может быть использована гидамиэкскурсоводами при проведении экскурсионных программ по города Сортавала.

Ключевые слова: Северное Приладожье, Сортавала, демография, миграции, естественный прирост, работы дореволюционных финских авторов.

\section{Abstract}

The article examines the demographic history of the city of Sortavala during the late 17th early 18th centuries. Sources on this issue are the documents of the National Archives of the Republic of Karelia and the works of pre-revolutionary Finnish scientists. The article can be used by tour guides when conducting excursion programs around the city of Sortavala.

Keywords: Northern Ladoga area, Sortavala, demography, national archives of the Republic of Karelia, migration, natural growth, works of pre-revolutionary Finnish authors.

Северное Приладожье является одним из самых востребованных в туристической индустрии Карелии мест для посещения и, безусловно, жемчужиной этого региона является город Сортавала, город с более чем четырехсотлетней историей. Экскурсии по Сортавале составляют неотъемлемую часть посещения Валаама и Рускеальского мраморного каньона и данные этой статьи, направленные на освещения истории города, могут быть использованы в работе профессионального экскурсовода.

История города Сортавала отражает сложную приграничную ситуацию, которая сложилась в XVII веке. В 1617 году, по Столбовскому мирному договору между Россией и Швеции, в состав Швеции вошел весь Корельский уезд, включая и НикольскоСердобольский погост. Долгое время считалось, что именно 1632 год является годом основания Сортавалы. Данная версия основывалась на сообщении Генрика Спорена 1633 года, в котором он сообщил правительству об основании прошлым летом, т. е. летом 1632 года двух погостов - Сортавалы и Салми. Данная дата основания является неверной. О том, что Сортавала возникла гораздо позднее - в 1643 году, свидетельствует распоряжение Густава II Адольфа, посланное им 17 июня 1632 года, в котором не упоминается Сортавала, а лишь дается общее распоряжение обдумать основание городов на реках Нева, в Карелии и Ингермаландии. Также обстояло дело и с основанием Сортавалы . По версии ученых У. Карттунена и Е. Куйо в письме Спорена вовсе не говорится об основании города, а лишь говорится о намерении основать город. Итак, идея основания Сортавалы была одобрена шведским правительством в 1632 году, но к основанию города приступили только в 1643 году

В 1637-1640 и 1648-1654 годах генерал-губернатором Финляндии был президент Верховного королевского суда Пер Брахе, который для ознакомления с краем совершал по нему долгие путешествия, занимался реорганизацией административного управления, организовывал почтовую службу и основывал новые города на подвластной ему территории. При нем был основан ряд торговых городов на водных путях Восточной Финляндии - Савонлинна (1639), Сортавала (1643), Лаппенранта (1649), Кайяни (1651), Брахеа (ныне Лиекса) (1652). Просьбу об основании города Сортавалы Брахе привез в парламент Стокгольма в 1642 году, и основанием города пришлось заняться тогдашнему 
генерал-губернатору Эрику Гилленштерне. Весной 1643 года начались переговоры с местными сельскими торговцами об их переезде в города Сортавала, Салми и Тайпале. Летом Гилленштерне в 1643 году посетил хелюльский приход и Сортавалу. Он указал точное место будущего города - деревню Келиемяляниеми.

Еще до основания города Сортавалы эта территория была заселена. В 1627-1635 годах в Сортавальской волости проживало около 189 семей (т. е 750-850 человек). С момента основания территория города начинает активно заселяться финнами. В принудительном порядке, а также по собственному желанию сюда стали переселять купцов из других погостов, и финнов из центральной Финляндии (1). По церковным книгам удается проследить, откуда прибывали жители в только что основанный город. По данным архивов, 19 семей происходили родом из Сортавальского прихода, 15 семей прибыли из южной Финляндии (области Ките), 3 семьи прибыли из Пялккаярви, из Тохмаярви прибыли 4 семьи, из Пиелисярви приехали 3 семьи, с области Саво - 2 семьи, из Импилахти, Париккалы и Куркиеки - по одной семье, с области Хяме - 2 семьи и из Каяни - 1 семья. Все семьи, переехавшие в город, имели финские фамилии. По происхождению переселенцы преимущественно были выходцами из крестьянского сословия. Вместе с тем в город приезжали, как редкое исключение, и отпрыски семей чиновников, военных и ремесленников, духовенства. Так, выходцы из духовенства носили латинизированные фамилии. К примеру, в Сортавале поселились сыновья первого приходского настоятеля Ките Хенрих и Юрье Валлиусы, брат приходского священника Тохмаярви Олаф Глумеруус и др.

Наряду с финским населением, в город стали переезжать и немногочисленные карельские семьи: Климпо (впоследствии в документах обозначенные как Климпонены, Кухнонены, Пукари), а также отдельные карельские переселенцы: Василий Миронпойка, Парфей Ходаринпойка). После войны с России 1656-1661 годов православное население, представленное карелами, оставило Сортавалу. На протяжении всего XVII века число карельских семей в городе было незначительным. Так, по сохранившемуся списку горожан за 1697 год, в котором регистрировались только главы семей, из 102 человек только 3 человека носили имена и фамилии, которые принадлежали карелам (Гаврил Павилов, Тарас Пуккари, Парфей Ходаринпойка). Остальные же имена по своему происхождению были шведскими и финскими.

Известно, что в середине XVIII века в городе по-прежнему проживали старинные городские роды, сложившиеся еще при старой шведской власти. Таких родов было всего 9 - Климпо или Климпуевы, Берг, Ниссинен, Иммонен, Лятти, Пирхонен, Симпанен, Тиайнен и Варпанен, и они составляли меньшинство среди горожан.

Наряду со старыми родами в город приезжали и новые поселенцы. Таковыми были Хейскуренены, Хопиа, Карьялайнены, Лаапотти, Лейкар, Лукка, Нокелайнены, Патья, Пелли, Ронканены, Рехканены, Саволайнены, Саукко, Тирри, Утуйнен, Беем, Болин, Бринк, Флорин, Фронделиус, Енгман, Хемминг, Лютхер, Помелл, Портанус, Ритчер, Сиберг, Силверхор.

В Сортавале жители четко делились на сословия - купцов и горожан-ремесленников. Эта сословная принадлежность передавалась по наследству. В середине XVIII века в Сортавале проживали 14 купеческих родов, торговавших маслом, дегтем, солью, мукой, сахаром, чаем, табаком, железом, скотом, галантереей, привезенной из России. Уже тогда выделились такие династии: Берг, Ниссинен, Болин, Саукко, Баас, Беем (Боем).

Ремесленниками в городе были Берг, Енгманн, Франтсон, Тирри, Симпанен, Керакайнен, Кохонен, Рехканен, Хейскуринен, Силферхор, Берлин, Кириллов, Саволайнен и Питканен.

По религиозной принадлежности большинство горожан были лютеранами, поскольку к этой конфессии относились все без исключения финны и шведы, переехавшие в Сортавалу с момента ее основания. Православными в XVII - первой четверти XVIII века в Сортавале были лишь немногочисленные карельские семьи. 
В Сортавала уже в XVII веке была православная церковь святого Николая. Она с давних пор стояла на острове Рантуе и на этом же месте в начале 1700-х годов была построена новая. После войны 1656-1661 годов православный приход был небольшим. Во время шведского правления православная церковь существовала с большими трудностями (1). С 1629 года шведские власти стали заботиться о предоставлении возможности исполнения обрядов лютеранской паствой, проживавшей в Северном Приладожье. Лютеранская церковь была построена в Хелюля, на северном склоне Паасонсалми. Церковь и дом лютеранского священника были уничтожены в войну 1656-1661 годов, и после наступления мира было начато строительство новой церкви в восточной части города на полуострове Кирккониеми. Церковь стала функционировать с начала 1670-х годов.

Интересно отметить, что горожане всячески содействовали обустройству церквей. Лютеранское население совместными усилиями собрало деньги на приобретение церковного колокола, за которым специально ездил в Стокгольм горожанин Антти Таскинен. Православные заботились о своей церкви не меньше, чем лютеране. Известный сортавальский православный купец Юрий Климпо купил на свои личные деньги 3 колокола и привез их из Стокгольма.

По данным съемки город представлял вытянутый с севера на юг прямоугольник площадью 8,5 га размерами 400 м шириной и до 270 м длиной. Береговая линия была на 20 м ближе к городу, чем сейчас(1).

Таким образом, Сортавала возникла как небольшой форпост шведской власти в Северном Приладожье и развивалась как небольшой торговый шведский город, жители которого были преимущественно финнами лютеранского происхождения с небольшим включением карельских православных семей.

$$
* * *
$$

1. Bjorn I. Suomalaisten Sortavala. Laatokan valkoinen kaupunri // Hakamies P. Sortavala - rajakaupunki. 2001.

2. Jaatinen M. Sortavalan rakentaminen. Espoo, 1997.

3. Karttunen Y. Sortavalan kaupungin historia. Sortavala, 1932.

4. PajamoR. Sortavala, Laatokan lauluva kaupunki. Joensuu, 1985.

5. Tiainen J. Sortavala Laatokan karjalan nousun aikana 1880-1918. Yvaskyla, 1970.

\section{Садиков P.P. \\ Кажаевские мурзы - этносословная группа мордвы (история и современность)}

Уфимский федеральный исследовательский цеентр РАН (Россия, Уфа)

doi: 10.18411/trnio-11-2021-132

\section{Аннотация}

В статье предпринят анализ этнокультурных особенностей группы мордовского населения Республики Башкортостан (с. Кожай-Андреево Туймазинского и с. КожайМаксимово Ермекеевского районов), именующей себя мурза («кажаевские мурзы»). Научная новизна заключается в том, что на основе исторических источников и полевых этнографических материалов впервые рассматриваются этнокультурные особенности мордвы этих поселений, обусловленные их сословным статусом в прошлом. В результате исследования показано, что мордву-мурзу можно выделить в отдельную этносословную общность, имеющую свои самосознание и самоназвание и обладающую языковыми и этнокультурными особенностями.

Ключевые слова: мордва-мурза, сословная группа, история формирования, этнокультурные особенности, Республика Башкортостан.

\section{Abstract}

The article analyzes the ethnocultural peculiarities of the group of the Mordovian population of the Republic of Bashkortostan (Kozhai-Andreevo settlement of Tuimazinsky and Kozhai- 